\title{
ADOPTIVE ADMISSIONS, ARREST AND THE PRIVILEGE AGAINST SELF-INGRIMINATION: A SUGGESTED CONSTITUTIONAL IMPERATIVE
}

When a person fails to deny an accusatory statement made in his presence, both the statement and the lack of response may (in some jurisdictions) be admitted into evidence as an adoptive admission to show either a consciousness of guilt or acquiescence in the truth of the statement. This result obtains whether the response is silence or an equivocal statement if the accused hears and understands the accusation, is free to reply and the context shows that the response is equivalent to acquiescence in or adoption of the charge. ${ }^{1}$

This rule of evidence is predicated upon the trustworthiness of the allowable inferences. The evidence is excluded when it is unreasonable to find that the natural reaction of an innocent person under the circumstances would be a denial..$^{2}$ If the accused is intoxicated, ${ }^{3}$ physically

1 Whether such evidence is admitted to show acquiescence in the truth of the statement or to show consciousness of guilt leads into controversies too intricate for complete discussion here. Two problems are central: developing a theory of admissions which does not conflict with the hearsay rule and fitting the adoptive admission into a general theory of admissions. The apparent conflict with the hearsay rule has been avoided by finding the hearsay rule satisfied, 4 WIGMORE, EvIDENCE $\$ 1048$ at 3 (3d ed. 1940) (hereinafter cited as WIGMORE), an exception to the rule, Morgan, Admissions as an Exception to the Hearsay Rule, 30 YALE L.J. 355, 359-61 (1921), and the hearsay rule inapplicable, Strahorn, A Reconsideration of the Hearsay Rule and Admissions, $85 \mathrm{U}$. Pa. L. Rev. 484, 488 (1937). See Note, 25 U. Cinc. L. Rev. 70 (1956). Silence occupies an ambiguous position in any theory which attempts to explain admissions generally, because it exhibits attributes belonging to both conduct and narrative evidence. Thus, there is no unanimity as to whether the inference is that the accused has assented to the statement permitting use of the admission for both impeachment and establishing the truth of the matter asserted or whether the inference is that of consciousness of guilt, in which case there is the further problem of whether finding a consciousness of guilt will support an inference relevant to a particular fact in the charge. See 4 WIGMORE $\$ \S 1048,1052,1071,1072 ; 2$ WIGMORE $\S 292$; Morgan, Admissions as an Exception to the Hearsay Rule, 30 YALE L.J. 355 (1921); Morgan, Admissions, 12 WASH. L.Q. 181 (1937); Morgan, Admissions, 1 U.C.L.A.L. REv. 18 (1953); Strahorn, $A R e$ consideration of the Hearsay Rule and Admissions, 85 U. PA. L. REv. 484 (1931); Maguire, Adoptive Admissions in Massachusetts, 14 Mass. L.Q. (1929). See generally, Brody, Admissions Implied from Silence, Evasion and Equivocation in Massachusetts Criminal Cases, 42 B.U.L. REv. 46 (1962); Note, 35 CoLUM. L. REv. 129 (1947); Note, 43 HaRv. L. Rev. 461 (1929); Note, 29 N.Y.U.L. REv. 1266 (1954).

2 E.g., Egan v. United States, 137 F.2d 369 (8th Cir. 1943); State v. Jackson, 150 N.C. 831, 64 S.E. 376 (1809). See cases collected 4 Wigmiore \& 1072; 2 Wharton, Criminal EVIDENCE §§ 656-662 (11th ed. 1935); Annot., 115 A.L.R. 1510 (1938).

3 People v. Allen, 300 N.Y. 222, 90 N.E.2d 48 (1949). 
unable to reply, ${ }^{4}$ unaware of the accusation, ${ }^{5}$ under instructions of an attorney, ${ }^{6}$ or not at liberty to reply, ${ }^{7}$ the courts have ruled that such a finding is not justified.

The silence ${ }^{8}$ of the accused while under arrest or in custody creates the most difficulty with respect to admissibility. ${ }^{9}$ The cases appear to fall into four categories: (1) those excluding the evidence on the basis of the privilege against self-incrimination;10 (2) those excluding because the accused is under no duty to speak; ${ }^{11}$ (3) those categorically excluding on the ground of inadequate probative value; ${ }^{12}$ and (4) those permitting an inference of guilt to be drawn even though the accused is under arrest. ${ }^{13}$

4 Ibid.

5 Arpan v. United States, 260 F.2d 649 (8th Cir. 1958).

B Commonwealth v. Ford, 199 Pa. Super. 102, 184 A.2d 401 (1962).

T People v. Briggs, 58 Cal. 2d 385, 374 P.2d 257 (1962).

8 "Silence" will be used here to refer to both a lack of response and an equivocal response, unless analysis requires that a distinction be made.

9 For a discussion of adoptive admissions in non-arrest situations, see Note $112 \mathrm{U}$. PA. L. Rev. 210, 216-34 (1963).

10 Helton v. United States, 221 F.2d 338 (5th Cir. 1955); People v. Simmons, 28 Cal. 2d 699, 172 P.2d 18 (1946); State v. Bowdry, 346 Mo. 1090, 145 S.W.2d 127 (1940); Comment, 11 De Paul L. Rev. 307 (1962); Note, 50 Ky. L.J. 592 (1962); Note, 5 Stan. L. REv. 459, 463-66 (1953); cf. State v. Stump, 119 N.W.2d 210 (Iowa 1963); Crabb v. State, 86 Okla. Crim. 323, 192 P.2d 1018 (1948); Ellis v. State, 8 Okla. Crim. 522, 128 Pac. 1095 (1913).

11 Ong Way Jong v. United States, 245 F.2d 392 (9th Cir. 1957); United States v. On Lee, 193 F.2d 306 (2d Cir. 1951), aff'd, 343 U.S. 747 (1952); United States v. Lo Biondo, 135 F.2d 130 (2d Cir. 1943) (per curiam); Yep v. United States, 83 F.2d 41 (10th Cir. 1936); McCarthy v. United States, 25 F.2d 298 (6th Cir. 1928) (per curiam); State v. Bates, 140 Conn. 326, 99 A.2d 133 (1953); Thomas v. State, 237 Ind. 537, 147 N.E.2d 577 (1958); Kern v. State, 237 Ind. 144, 144 N.E.2d 705 (1957) (dictum); State v. Weaver, 57 Iowa 780, 11 N.W. 675 (1882) (citing Massachusetts "no duty" cases); State v. Hayden, 243 La. 793, 147 So. $2 d 392$ (1962); Cooper v. State, 231 Md. 248, 189 A.2d 620 (Ct. App. 1963); Miller v. State, 231 Md. 215. 189 A.2d 635 (Ct. App. 1963); Commonwealth v. Silvia, 343 Mass. 130, 177 N.E.2d 571 (1961); Commonwealth v. McDermott, 123 Mass. 440 (1877); State v. Vainikos, 366 S.W.2d 423 (Mo. 1963); State v. Epstein, 25 R.I. I31, 55 Atl. 204 (1903); Redding v. State, 149 Tex. Crim. 576, 197 S.W.2d 357 (1946); State v. Tembruell, 50 Wash. 2d 456, 312 P.2d 809 (1957); State v. Redwine, 23 Wash. 2d 467, 161 P.2d 205 (1945). See State v. Gulbrandsen, 238 Minn. 508, 57 N.W.2d 419 (1953); State v. Brown, 209 Minn. 478, 296 N.W. 582 (1941); Riger v. State, 249 Wis. 201, 23 N.W.2d 456 (1946). Contra, McDonald v. State, 193 Wis. 204, 212 N.W. 635 (1927).

12 Commonwealth v. Sazama, 339 Mass. 154, 158 N.E.2d 313 (1959) (dictum); People v. Rutigliano, 261 N.Y. 103, 184 N.E. 689 (1933) (the court also uses "no duty" language); O'Hearn v. State, 79 Neb. 513, 113 N.W. 130 (1907) (the inference prohibited on the facts of the case, the court did not adopt but seemed to approve, evidentiary reasoning which argued for a per se arrest rule); State v. Brown, 209 Minn. 478, 296 N.W. 582 (1941) (dictum) (the court did not adopt, but seemed to approve, the per se rule).

13 Sparf v. United States, 156 U.S. 51 (1895); Rocchia v. United States, 78 F.2d 966 (9th Cir. 1935); Dickerson v. United States, 65 F.2d 824 (D.C. Cir. 1933), cert. denied, 290 U.S. 665 (1933); Pritchett v. State, 40 Ala. App. 498, 117 So. 2d 345 (1959), cert. 
The burden of this comment is to show that in the first group of cases privilege doctrine is used correctly to prohibit the inference, that all other cases which categorically exclude the evidence cannot be supported by their internal reasoning and should rest on an analysis based on the privilege. Further, it will be shown that the cases in the last category, permitting the inference, cannot be reconciled with a privilege doctrine that would deny a similar inference where the privilege is exercised at trial. ${ }^{14}$

The admissibility of an accused's silence during arrest is ultimately a problem of inference. If the privilege is applicable to the arrest situation, admissibility will turn upon whether inferences adverse to the defendant may be drawn from its assertion. And even if it is found that the privilege should apply only where a testimonial duty has been legally imposed, the issue of inference remains the same. It is suggested here

denied, 270 Ala. 211, 117 So. 2d 347 (1960); State v. Lubetkin, 78 Ariz. 91, 276 P.2d 520 (1954); Moore v. State, 229 Ark. 335, 315 S.W.2d 907 (1958), cert. denied, 358 U.S. 946 (1959); People v. Simmons, 28 Cal. 2d 699, 172 P.2d 18 (1946) (dictum); People v. Yeager, 194 Cal. 452, 229 Pac. 40 (1924); Cook v. People, 56 Colo. 477, 138 Pac. 756 (1914) (dictum); Mezzatesta v. State, 53 Del. (3 Storey) 145, 166 A.2d 433 (1960); Albano v. State, 89 So. 2d 342 (Fla. 1956); Hannah v. State, 212 Ga. 313, 92 S.E.2d 89 (1956) (dictum); People v. Smith, 25 Ill. 2d 219, 184 N.E.2d 841 (1962); People v. Kozlowski, 368 Ill. 124, 13 N.E.2d 174 (1938) (dictum); Smith v. Commonwealth, 366 S.W.2d 902 (Ky. 1963); People v. Kregger, 335 Mich. 457, 56 N.W.2d 349 (1953); Goldsby v. State. 240 Miss. 647, 123 So. 2d 429 (1960); State v. Won, 76 Mont. 509, 248 Pac. 201 (1926); State v. Wargo, 83 N.H. 532, 145 Atl. 456 (1929) (dictum); State v. Landeros, 20 N.J. 76, 118 A.2d 524 (1955), cert. denied, 351 U.S. 966 (1956); State v. Kane, 9 N.J. Super. 254, 75 A.2d 894 (1950) (the authority of the New Jersey cases should be reappraised in light of dicta in State v. Butler, 32 N.J. 166, 160 A.2d 8, cert. denied, 362 U.S. 984 (1960)); Skidmore v. State, 59 Nev. 320, 92 P.2d 979 (1939) (privilege construed to refer to only testimonial compulsion); State v. Case, 253 N.C. 130, 116 S.E.2d 429 (1960), cert. denied, 365 U.S. 830 (1961) (before arrest); State v. Jackson, 150 N.C. 831, 64 S.E. 376 (1909) (dictum) (before arrest); Murphy v. State, 36 Ohio St. 628 (1881) (see State v. Jackson, 64 Ohio L. Abs. 413, 112 N.E.2d 80 (Ct. App. 1951) (before arrest but during custody). But see Walker v. State, 37 Ohio App. 540, 175 N.E. 29 (1930)); Commonwealth v. Vento, 410 Pa. 350, 189 A.2d 161 (1963) (dictum); Commonwealth v. Vallone, 347 Pa. 419, 32 A.2d 889 (1943); State v. Hester, 137 S.C. 145, 134 S.E. 885 (1926) (dictum); State v. Fogg, 115 N.W.2d 889 (S.D. 1962); Oliver v. State, 208 Tenn. 692, 348 S.W.2d 325 (1961) (before arrest); People v. Kessler, 13 Utah 69, 44 Pac. 97 (1896) (by implication) (see State v. Erwin, 101 Utah 365, 120 P.2d 285 (1942) (before arrest or custody)); Tillman v. Commonwealth, 185 Va. 46, 37 S.E.2d 768 (1946) (before arrest); State v. Booker, 68 W. Va. 8, 69 S.E. 295 (1910). See State v. Poynter, 34 Idaho 504, 205 Pac. 561 (1921) (but cf. State v. Bubis, 39 Idaho 376, 227 Pac. 384 (1924)).

14 The federal privilege against self-incrimination has not been incorporated into the due process clause of the fourteenth amendment. Adamson v. California, 332 U.S. 46 (1947); Twining v. New Jersey, 211 U.S. 78 (1908); cf. Palko v. Connecticut, 302 U.S. 319 (1937). A case before the Supreme Court this term, however, poses the question anew. Malloy v. Hogan, 150 Conn. 220, 187 A.2d 744, cert. granted, 373 U.S. 948 (1963). Nevertheless, the privilege exists in state constitutional provisions, and it has been asserted that the specific language is not determinative since a common idea informs each provision. 8 WIGMORE $\S \S 2252,2263$ (McNaughton Rev. 1961) [hereinafter cited as 8 WIGMORE]. 
that the silence of an accused during arrest is sufficiently analogous as a practical matter to the exercise of the privilege to make the question of whether silence is admissible turn upon whether negative inferences may be drawn from an assertion of the privilege. Thus, in all cases, the doctrine concerning adverse inferences from an assertion of the privilege should determine the admissibility of an accused's silence in response to statements made during arrest.

\section{I}

Before reaching the question of inference the threshold issue is whether the privilege is applicable to statements obtained in situations where no testimonial duty has been imposed.

It has been argued that the privilege is inapposite where testimonial compulsion is absent, thus precluding its application in the arrest situation where the interrogator lacks the legal power to compel response. In Owens $v$. Commonwealth, ${ }^{15}$ police accused the defendant of robbery by reading to him the confession of an accomplice. Although reversing the conviction on other grounds, the court sustained the admission of evidence of the defendant's silence in response to the confession, rejecting the contention that doing so violated the privilege against self-incrimination. The court, following Wigmore's view, ${ }^{16}$ reasoned that the privilege is concerned with testimonial compulsion and cannot apply to extrajudicial interrogations, where, as in the arrest situation, the defendant is under no legal duty to speak. In Wood $v$. United States, ${ }^{17}$ relied upon in Owens, the court limited the privilege to proceedings of a judicial nature where the state has imposed a duty to disclose, reasoning that the privilege assures a defendant only that judicial power will not be enlisted on the side of the prosecutor to assist him in obtaining a conviction.

Neither the case law nor the history of the privilege unambiguously support the narrow reading given it in Owens. History is invoked both by those who view the privilege as applicable only to judicial proceedings and by those who view it as operative during police interrogation. The former rely upon the fact that the privilege developed in response to the practice of compelling an accused to take an oath in answering accusations before English ecclesiastical tribunals. ${ }^{18}$ The latter regard the historical development to be largely the product of attempts to protect the

15186 Va. 689, 43 S.E.2d 895 (1947) (before arrest but during custody).

168 WIGMORE \& 2252 , at 329 n.27.

17 128 F.2d 265 (D.C. Cir. 1942) (dictum). Contra, Bullock v. United States, 122 F.2d 213 (D.C. Cir. 1941) (dictum).

188 WIGMORE $\S \S 2250,2252$ at $270,291,324$. 
individual against the extensive powers of investigation possessed by agencies of the state.

Helton $v$. United States ${ }^{19}$ clearly takes the latter view by associating the history of the preliminary inquisition with contemporary police functions. The court there held that the privilege forbade inferring guilt from the accused's failure to explain the presence of marijuana found on his property. The court concluded that the protection of the privilege begins before trial, since "it was the preliminary inquisition . . . which gave rise to the abuses, which resulted in the recognition of the privilege against self-incrimination."20 A similar view is adopted in People $v$. Simmons. ${ }^{21}$ The defendant was accused of robbery and murder; while the police were taking him to the station he gave an alibi, and the officers accused him of lying. He replied, "I have told you all I am going to say." At the station, he was confronted with the written statements of witnesses accusing him of the crime and the same response was given. The court found error in the admission of the colloquy because it considered the defendant to have attempted to assert his privilege. The striking feature of the Simmons opinion is its preoccupation with police practices. Engaging an accused in conversation when he is reluctant to speak and reading long statements of accusation to him were condemned. Such practices were regarded as coercive, "no different than if a gun were held at his head to compel him to talk . . ."22 Throughout the opinion it is obvious that the court is seeking to protect the accused's privilege to remain silent in the face of police interrogation. ${ }^{23}$ The con-

19221 F.2d 338 (5th Cir. 1955).

$20 \mathrm{Id}$. at 342.

2128 Cal. 2d 699, 172 P.2d 18 (1946).

$22 I d$. at 719,172 P.2d at 29.

23 The court's view in Simmons that the defendant's actions were an attempt to assert a right suggests an alternative reading of the case. The conclusion may be a response to the question of whether an explicit invocation of the privilege is sufficient grounds for refusing to admit the statement as possible evidence of guilt on the basis of its lack of probative value. Courts have ruled that when an accused specifically asserts the privilege, no inference is permissible. E.g., People v. McFarland, $26 \mathrm{Cal}$. Repr. 473, 376 P.2d 449 (1962); Commonwealth v. Ford, 113 Pa. Super. 588, 165 A.2d 113 (1960). But it cannot always be said that an inference of guilt from an assertion of the privilege is unreasonable if the test is how an innocent person would react to an accusation. It has been said that asserting the privilege is the expression of something neither an affirmance nor a denial, see Kelley v. United States, 236 F.2d 746, 749-51 (D.C. Cir. 1956), but this begs the question as to whether the inference is proper, for under the theory of adoptive admissions, equivocal statements are regarded along with silence as responses which may indicate consciousness of guilt. See note 1 supra. The plea of the privilege has no magical quality to distinguish it from any other equivocal response if the privilege is inappropriate in extrajudicial circumstances. Thus, the result can be justified only if the courts are finding that the claim of the privilege during arrest was legally appropriate and that to draw inferences from its invocation is improper. See text accompanying notes 53-69 infra. 
clusion seems inescapable that Simmons, like Helton, interprets the privilege as a limitation upon the power of an agency of the state to obtain the assistance of an accused in his own conviction, albeit neither makes explicit the permissible scope of state power.

In interpreting the history of the privilege, commentators have placed different emphasis upon the factors of procedural fairness, ${ }^{24}$ use of the oath, ${ }^{25}$ and jurisdictional disputes between Crown and Church over the ecclesiastical courts ${ }^{26}$ to justify varying conclusions as to the present policy of the privilege. The view taken in Helton and Simmons does not lack historical support. Even though the phases of the historical development give rise to no certain interpretation, an examination of that development shows that the original purpose of the privilege would not be perverted by applying it to arrest situations.

It is generally agreed that the significant event was the trial of John Lilburne, 27 a Leveller, who was punished by the Court of Star Chamber in 1638 for refusing to take the oath ex officio. ${ }^{28}$ Emphasis has been placed upon Lilburne's predicament of being punished either for refusing to swear an oath or for the disclosure which the oath compelled. ${ }^{29}$ The reaction to the trial suggests that this dilemma was found to be intoler-

24 Morgan, The Privilege Against Self-Incrimination, 34 MrNn. L. REv. 1, 9 (1949).

25 Meltzer, The Privilege Against Self-Incrimination, The New Republic, Mar. 4, 1955, p. 18. See Meltzer, Required Records, The McCarran Act, and the Privilege Against Self-Incrimination, 18 U. CHI. L. REv. 687, 692-93 (1951).

208 Wigmore \& 2250. See Pittman, The Colonial and Constitutional History of the Privilege Against Self-Incrimination in America, 21 VA. L. REv. 763 (1935).

27 See 8 Wigmore $\S 2250$, at 282; Morgan, supra note 24, at 9; Corwin, The Supreme Court's Construction of the Self-Incrimination Clause, 29 Mrch. L. REv. 1, 9 (1930).

28 The oath ex officio was a device widely employed in combatting heresy. MAYERS, Shall We Amend the Fifth Amendment 12-14 (1959). Lilburne was charged with printing and importing heretical and seditious books. Upon his refusal to take the oath, the Council of the Star Chamber condemned him to be "whipped and pilloried, for his 'boldness in refusing to take a legal oath', without which many offenses might go 'undiscovered and unpunished ...." 8 WIGMORE $\S 2250$, at 283. Trial of Lilburne \& Wharton, 3 How. St. Tr. 1315 (1637).

29 "The 'cruelty' of compulsory interrogation under oath generally results from the fact that such compulsion gives the suspect, whose answers would be incriminating, a set of harsh choices: perjury and the risk of temporal, and for the religious, divine punishment; self-incrimination; or silence and punishment for contempt. It was the harshness of these choices which Lilburne suggested in opposing interrogation under oath by the Court of Star Chamber. 'This oath,' he said, 'is against the very law of nature; for nature is always a preserver of itself, not a destroyer; but if a man takes this wicked oath, he destroys and undoes himself." Meltzer, The Privilege Against Self-Incrimination, The New Republic, Mar. 4, 1955, p. 18. A similar dilemma has been found to exist when a person is confronted with accusations in the police station, for he must choose between the risks of having his words used against him or his silence used to support an inference of guilt. E.g., Bram v. United States, 168 U.S. 532, 562-63 (1897); McCarthy v. United States, 25 F.2d 298, 299 (6th Cir. 1928) (per curiam). 
able. A crisis was provoked which in 1641 resulted in a grant of reparation to Lilburne and the abolition of the Courts of Star Chamber and High Commission by the Long Parliament. ${ }^{30} \mathrm{~A}$ bill was passed the same year forbidding the administration of the oath ex officio by any ecclesiastical official. ${ }^{31}$ The principle that a person could not be compelled by oath to accuse himself won recognition in the common-law courts, ${ }^{32}$ so that before the middle of the eighteenth century the privilege was firmly established in English law. ${ }^{33}$

By focusing upon the specific device of the oath or the early claims against improper procedure or the dispute over the jurisdiction of the ecclesiastical courts, commentators have cautioned against sentimentally ascribing a greater scope to the privilege than its ancient operation suggests. ${ }^{34}$ The isolated development of rules concerning coerced confessions and the fact that torture was practiced contemporaneously with the privilege gives weight to their warning. But limiting an explanation of the privilege to the specific forms in which it was first manifested slights the purpose which these forms may reasonably be said to have been intended to serve. If the defendant's dilemma is no longer specifically a choice between prison and damnation, it remains important to ask why it was thought necessary to save him from that dilemma. And the answer may be that it is demanded by notions of individual dignity which remain equally cogent today.

It is significant to this writer that the privilege gained recognition at approximately the same time the odious investigatory courts were abolished, indicating that the sentiments which nourished development of the privilege were directed against abusive investigatory powers wielded by the Crown. That a struggle against prosecution for heresy prompted recognition of the privilege reinforces the thesis that the important issue was that of the proper exercise of state power over the individual. The elevation in the United States of the English common-law rule to a constitutional principle lends support to this view, for the special American concern for the privilege has been traced to colonial opposition to ex officio methods employed by Councils of the Royal Governors. ${ }^{35}$

By viewing the emergence of the privilege as an incident in develop-

308 WIGMORE § 2250, at 283.

31 Id. at 284 .

32 The case development from Lilburne's trial to the recognition of the privilege in the common-law courts is set forth in 8 WIGMORE § 2250, at $284 \mathrm{n} .71-72$, at 289-90 nn.102-05, and in Morgan, supra note 24, at 9-12.

338 WIGMORE § 2250, at 284; Morgan, supra note 24, at 12.

348 Wigmore $\$ 2266$, at 401; Mayers, op. cit. supra note 28, at 9-19; Morgan, supra note 24 , at $12-15$.

35 Pittman, supra note 26 , at 27-38. 
ments which groped for a definition of the proper scope of governmental power over the citizen rather than merely over the criminal defendant, the arguments which would restrict the privilege lose some of their force. The oath ex officio may not be significant because it made the early examinations resemble judicial proceedings; part of its importance derives from the use of the oath by the state as an instrument for compelling an accused to convict himself. Although history cannot justify a reinterpretation, since the ambiguities of the origins of the privilege are apparent, the explanation offered here suggests that applying the privilege to arrest situations is consistent with the meaning which history seems to impart.

Some states have explicitly used the privilege in arrest situations, ${ }^{36}$ but the majority of jurisdictions have not resolved the question. The federal decisions are not unambiguous and there is respectable authority for applying the doctrine of the privilege to arrest situations. In Bram $v$. United States, ${ }^{37}$ the Supreme Court relied upon the privilege to reverse a conviction based in part upon statements given to an investigating official. Although the accused was subjected to intimidating conduct while being questioned about his participation in a shipboard murder, the Court clearly rested upon the privilege rather than due process to exclude the defendant's statements. The case has been criticized, ${ }^{38}$ but there are indications that subsequent to Bram and prior to the development of the confessions rule based on the supervisory power, ${ }^{39}$ the Supreme Court used the privilege to reject confessions coerced by federal officers. At the least, it is clear that the Court has never rejected the use of the privilege in arrest situations. Ziang Sung Wan $v$. United States ${ }^{40}$ involved a confession obtained by federal officers which was rejected by the Court as involuntary. No constitutional provision was cited, nor any rule of evidence referred to, but the Court relied upon Bram for the proposition that "a confession obtained by compulsion must be excluded whatever may have been the character of the compulsion, and whether the compulsion was applied in a judicial proceeding or otherwise."41 The petitioner's brief makes clear that the ground upon which reversal was

36 Cases cited note 10, supra. By statute, New Jersey provides that, subject to waiver, every natural person has a right to refuse to disclose to a police officer matters that will incriminate him. N.J. STAT. ANN. $\S 2 A-84$ A-19 (Supp. 1963). See cases cited, 8 WIGMORE $\$ 2252$, at 329 n.27.

37168 U.S. 532 (1897).

38 See, e.g., 8 WIGMORE $\$ 2252$, at 329 n.27.

39 Anderson v. United States, 318 U.S. 350 (1943); McNabb v. United States, 318 U.S. 332 (1943).

40266 U.S. 1 (1924) (per Brandeis, J.).

41 Id. at 14-15. 
urged was the violation of the privilege against self-incrimination. ${ }^{42}$ Similarly, in $M c N a b b v$. United States ${ }^{43}$ and Anderson v. United States, ${ }^{44}$ two federal confessions cases decided together, the briefs argued whether petitioners' confessions were involuntary under the federal privilege against self-incrimination. ${ }^{45}$ The American Civil Liberties Union filed a brief as amicus curiae solely on that point. ${ }^{46}$ The only mention of the possibility that the privilege was inapplicable because the confessions were obtained during arrest is a footnote in the Government's brief in Anderson which refers to Wigmore's position, but concedes that the federal courts have not followed him, citing Bram and Ziang Sung Wan.47 The Court in $M c N a b b$ did not reach the constitutional question, preferring to rely upon the power of the Supreme Court to supervise criminal procedure in federal cases, ${ }^{48}$ but the constitutional provision informing the decision of the Court was clearly the privilege against self-incrimination. ${ }^{40}$

In light of this authority and history, it cannot be maintained that use of the privilege to exclude evidence obtained during arrest is a distortion of privilege doctrine. The cases which regard the privilege as excluding inferences of guilt from an accused's silence at arrest are on solid ground in finding the privilege against self-incrimination a limitation upon police inquiry as well as upon the power of courts.

42 Brief for Petitioner, pp. 151-54, Ziang Sung Wan v. United States, 266 U.S. 1 (1924).

43318 U.S. 332 (1943).

44318 U.S. 350 (1943).

45 Brief for the United States, pp. 28-49, Anderson v. United States, 318 U.S. 350 (1943); Brief for the United States, p. 17, Memorandum for Petitioner, pp. 5-6, McNabb v. United States, 318 U.S. 332 (1943).

46 Brief on Behalf of American Civil Liberties Union as Amicus Curiae, pp. 2-7, Anderson v. United States, 318 U.S. 350 (1943).

47 Brief for the United States, at $40-41$ n.44, Anderson v. United States, 318 U.S. 350 (1943).

48 See Note, 76 Harv. L. Rev. 1656 (1963).

$49 \mathrm{Mr}$. Justice Reed, dissenting, explicitly stated that the appropriate standard for determining whether the confessions were admissible was that of the federal privilege against self-incrimination. 318 U.S. at 349. To him, the confessions were clearly voluntary and, hence, admissible. But he went further and protested the Court's use of the supervisory power to demand higher standards of conduct from federal law enforcement officers than would be necessary under the privilege against self-incrimination. This last contention provides a meaningful insight into the subsequent history of the use of the federal privilege in arrest situations, for it dispels the argument that the Court's failure to employ the privilege is a rejection of its application during arrest. The contention supports the opposite conclusion that Bram and Ziang Sung Wan are still good law, for it attributes the lack of use of the federal privilege in arrest situations to the Court's ability to demand stricter standards of behavior for federal law enforcement officials under the supervisory power. Thus, subsequent to $M c N a b b$, the constitutional question need never be reached. 
Even though the privilege might be construed to apply only where a testimonial duty is imposed, silence during arrest is analogous to the exercise of the privilege at trial. In neither case can the accused be placed under a legal duty to speak. During arrest, the accused is under no duty to answer police interrogatories, nor can he be placed under such a duty. Even the Wigmore view of the privilege would be violated by giving police contempt power or the authority to obtain a court order directing an accused to answer. At trial, a defendant is under no duty to testify; the powers of the court cannot compel him to speak, for the privilege assures him of an option to remain silent. The privilege at trial removes for defendants the ordinary testimonial duty, thereby placing them on a plane equivalent to that of the accused in the police station. ${ }^{50}$ Thus, the rules controlling inferences from an exercise of the privilege at trial should also control inferences from silence during arrest, for in both cases the question is the same-whether a negative inference should be drawn from the silence of one who exercises the privilege of remaining mute. ${ }^{51}$

A majority of jurisdictions, by statute, prevent drawing an adverse inference from a defendant's refusal to testify, ${ }^{62}$ and the prohibition has been extended to a valid exercise of the privilege by a defendant who has taken the stand. ${ }^{53}$ Thus, if the rule during trial is that a defendant cannot be prejudiced by suffering a legal detriment for remaining silent, the defendant should be protected from a similar detriment at arrest. It has been argued that the very existence of the privilege at trial creates a need for leeway in the police station. Nevertheless, it may still be asked whether creating an adverse inference from an ac-

50 An indiscriminate extension of the position taken here might lead to the conclusion that all trial standards should be imposed during arrest, thus vitiating traditional interrogation and confessions. It is not urged here that such extension is either necessary or desirable. The privilege doctrine suggested for arrest is consistent with both its history and policy. Similar considerations would seem appropriate in determining any further extension.

51 The similarity between adoptive admissions and inferences from a defendant's refusal to testify has been recognized, although usually in making the opposite argument that the inference from the privilege should be permitted. People v. Adamson, 27 Cal. 2d 478, 165 P.2d 3, 8-9 (1946), aff'd, 332 U.S. 46 (1947); State v. Cleaves, 59 Me. 298 (1871); State v. Baker, 115 Vt. 94, 108, 53 A.2d 53 (1947); Bruce, The Right to Comment on the Failure of the Defendant to Testify, 31 MrcH. L. REv. 226, 233 (1932).

52 See cases cited 8 WIGMORE $\S 2272$, at n.2; Reeder, Comment Upon Failure of Accused To Testify, 31 Mrch. L. REv. 40 (1932); Annot., 68 A.L.R. 1108 (1930); Annot., 171 A.L.R. 1267 (1947). But see UNIFORM RULES OF EvIDENGE, rule 23(4); MODEL CODE OF EvIDENCE, rule 201(3).

53 Johnson v. United States, 318 U.S. 189, 196 (1943) (dictum). 
cused's silence even though he has no right to counsel and no assurance through publicity that he is safe from physical coercion comports with our sense of individual dignity. The question is not whether we need leeway during police interrogation, but what are the proper limits on the criminal process. It is submitted that considerations of proper policy must lead to the exclusion of adverse inferences both during arrest and at trial,, 54 even though the strict words of the "no-comment" statutes might seem not to embrace the arrest situation.

Nevertheless, should such a result be reached, a constitutional hurdle must be overcome. Since the propriety of the inference turns upon whether inferences from an exercise of the privilege are permissible, the constitutionality of inferring guilt from an exercise of the privilege is crucial. Only a few courts have passed on this question for the statutes prohibiting comment were usually part of legislation removing defendants' common-law disability as witnesses; ${ }^{55}$ thus, for most jurisdictions, the question of whether an inference from the privilege is appropriate was answered by statute.

In State $v$. Wolfe, ${ }^{56}$ because of a statute permitting comment by counsel on a defendant's refusal to testify, the court was required to determine the constitutionality of the prosecutor's comment on the defendant's silence. The argument was accepted that permitting comment compels a defendant to testify, and the comment was declared a violation of the defendant's constitutional privilege against self-incrimination. ${ }^{67}$ The Wolfe opinion seems to represent the appropriate constitutional analysis. 58 Even the proponents of the constitutionality of comment recognize that it subjects a defendant to some pressure to testify. ${ }^{50}$ Only the Wolfe result preserves the sweep of the constitutional

54 Any distinctions that can be made, in fact, argue for a more lenient rule of inference at trial than at arrest. Perhaps the trial, since it is the last opportunity for the prosecution to obtain a conviction requires a more relaxed rule concerning comment so that all the relevant considerations will be before the court. Perhaps the protection surrounding the defendant at trial weakens the feeling that fairness has been violated by permitting comment upon the defendant's refusal to take the stand. In England the judge may comment upon a defendant's refusal to testify although such power is forbidden the prosecution. CROss, EvIDENCE 38-39, 171 (1958). But during arrest the Judges' Rules limit the scope of police interrogation and require cautioning an accused who is to be charged with a crime; no inferences can be drawn from an accused's silence after the warning has been given. CRoss, op. cit. supra, at 139-40; Phipson, Evidence 767, $801-809$ (10th ed. 1963).

55 See generally, 8 WIGMORE $\S 2272$.

56 64 S.D. 178, 266 N.W. 116 (1936).

57 Id. at 187, 266 N.W. at 120.

58 Accord, People v. Tyler, 36 Cal. 522 (1869).

59 People v. Adamson, 27 Cal. 2d 478, 486, 165 P.2d 3, 7 (1946), affd, 318 U.S. 189 (1947); State v. Baker, I15 Vt. 94, 105, 53 A.2d 53, 59 (1947); In re Opinion of the 
protection, for if the proposition is granted that an assertion of the privilege is legally consistent with innocence, ${ }^{60}$ any argument which seeks to justify pressuring even innocent persons into testifying must be discarded as derogating the extent of the privilege.

Three arguments have been urged in rebuttal: (I) that the privilege was not intended to apply to this particular kind of coercion;61 (2) that the coercion to testify exists independently of the rule allowing comment, since a jury will always notice a defendant's refusal to testify; ${ }^{62}$ and (3) that the innocent have nothing to fear from testifying, while whatever dilemma the guilty experience is created by their own lawlessness. ${ }^{63}$

The argument that the privilege was intended to protect an accused from torture and inquisitorial practices, not from the indirect pressure to explain incriminating evidence is dubious. There is strong evidence that from its inception the privilege defined a relationship between the individual and the state in which it was not the form of the coercion, but the exercise of state power to compel an accused to aid in his conviction to which the privilege was directed. The fact that the limitation has sanctity primarily as applied to utterances and not to conduct of the accused indicates only that the major concern has been with the psychological dilemma, a dilemma that exists equally during arrest and at trial. ${ }^{64}$ In the words of the Massachusetts court (holding a statute permitting comment unconstitutional) "the protection afforded by the Constitution is that the individual shall not be prejudiced at law by his silence, if he keeps silent."65

Given the nature of the criminal trial, it is difficult to accept the second proposition that a defendant who does not testify is in no worse position when the prosecutor may comment than when he may not. Even though a jury may notice a failure to testify it may not be moved by it.60 The question is whether the law can impose a sure disability

Justices, 300 Mass. 620, 629-30, 15 N.E.2d 662, 667 (1938) (dissent); State v. Wolfe, 64 S.D. 178, 189-90, 194, 266 N.W. 116, 121-22, 124 (1936) (dissents).

60 Grunewald v. United States, 353 U.S. 391,422 (1957).

61 E.g., State v. Baker, 115 Vt. 94, 53 A.2d 53 (1947).

62 State v. Wolfe, 64 S.D. 178, 197, 266 N.W. 116, 125 (1936) (dissent). The suggestion that by allowing the defendant to testify, he is coerced, was made in Ruloff v. People, 45 N.Y. 213 (1871) (dictum), but the contention that this was sufficient to violate the privilege against self-incrimination was rejected in People v. Courtney, 94 N.Y. 490 (1884).

63 E.g., State v. Cleaves, 59 Me. 298 (1871); State v. Baker, 115 Vt. 94, 53 A.2d 53 (1947).

64 Bram v. United States, 168 U.S. 532 (1897).

65 In re Opinion of the Justices, 300 Mass. 620, 624, 15 N.E.2d 662, 664 (1938).

68 See Bruno v. United States, 308 U.S. 287, 294 (1939). It has been argued that it is absurd to ignore a fact which any person of average intelligence would take into 
by permitting the prosecutor to play upon that failure and the court to instruct that legal significance attaches to a defendant's silence. ${ }^{67}$

The third contention that the innocent have nothing to fear from testifying, even if accepted, proves too much. The essence of the privilege is the protection from being coerced by government into giving evidence against oneself. Even though a defendant's fears are fanciful (a doubtful assumption in view of impeachment and cross-examination techniques), he cannot be compelled to testify. The contention that whatever pressure to testify is created by the comment can do no harm rests upon a notion of the relationship between state and individual in the administration of criminal justice which conflicts with the policy of the privilege-a conflict vividly seen in the argument that those who are guilty deserve no better treatment than to face the dilemma of incrimination either through their testimony or the inferences to be drawn from their silence. 68

Thus, in all those jurisdictions which prohibit comment, an inference of guilt drawn from silence during arrest should be prohibited. Regardless of whether the privilege is viewed as applicable in terms to arrest situations, the propriety of the inference depends upon the permissibility of drawing an adverse inference from the exercise of the privilege at trial. Where the exercise at trial is protected from adverse inferences by specific statutory language, consistency demands that these same jurisdictions prohibit the inference from silence during arrest. And even if the statutory provisions are construed narrowly the unconstitutionality of inferences drawn from the use of the privilege at trial compels the rejection of inferences drawn from an accused's silence during arrest.

\section{III}

If the privilege has been waived, however, the inference from an accused's silence would be permissible. Waiver from failure to claim

account, but all the argument establishes is that the inference might be valid. That is not the issue. "The question is whether the inference, though not denied, should not be ignored-whether principle and expediency require us to prevent, so far as feasible, any further use of the inference than is inevitable from the mere disclosure of the claim." 8 WIGMORE § 2272 , at 426.

67 If the policy of the privilege is restricted to the proposition that it guarantees the diligence of the prosecutor in obtaining independent evidence for conviction, a case can be made for the consistency of comment with the privilege. Since a prosecutor cannot rely upon comment to establish his case, his efforts to secure evidence will not be affected. Dunmore, Comment on Failure of Accused to Testify, 26 YALE L.J. $464,469-70$ (1917). But if defendants would be more prone to testify when the prosecutor can comment on their failure to do so, it is not unlikely that to some extent the prosecutor will rely on the stratagem of comment to win his cases.

68 For an extreme example, see Note, 37 Mrcr. L. REv. 777 (1939). 
the privilege explicitly has been found at trial, ${ }^{69}$ but the circumstances of arrest suggest a rejection of this doctrine when applied to an accused under police examination. During arrest, no testimonial obligation exists. By refusing to answer the accused is exercising a general privilege not to respond-a situation unlike that of trial where the privilege removes an otherwise existing duty to testify. Moreover, since the interrogator lacks the authority to determine the merits of a claim of the privilege, the requirement of an explicit claim cannot serve the minimal function of informing the court of the necessity of ruling upon the claim. ${ }^{70}$

To require an explicit claim leads to curious results. In Commonwealth $v$. Towber, 71 it was disputed whether the defendant in fact invoked the privilege during police interrogation. All the evidence was admitted at trial and the jury was told to consider the defendant's silence as evidence of guilt if they believed he did not raise the privilege, but to draw no inferences if they believed he asserted a constitutional right. ${ }^{2}$ The difficulties of proving an assertion of the privilege will be great. Allowing the jury to determine whether the privilege was invoked implies reliance upon its ability to erase the evidence from memory if it is found unacceptable.73 As the accused will be without counsel and perhaps without knowledge of his rights, a requirement that he suffers for his silence by not making clear his reasons for remaining mute thus seems an unwise extension of the trial doctrine of waiver.

Modification of other aspects of trial waiver doctrine also seems to be demanded. Considerations of fairness to an opposing party which require at trial preservation of cross-examination and protection against mis-

69 Rogers v. United States, 340 U.S. 367, 370-71 (1951) (dictum); see Quinn v. United States, 349 U.S. 155, 162-63 (1955) (it is sufficient to use language which gives a reasonable expectation that the privilege is being invoked); Emspak v. United States, 349 U.S. 190, 194 (1955). Silence has been said not to constitute a claim of the privilege. United States ex rel. Vajtauer v. Comm'r, 273 U.S. 103, 113 (1927).

70 See United States ex rel. Vajtauer v. Comm'r, supra note 69, at 113.

71190 Pa. Super. 93, 152 A.2d 917 (1959).

72 An analogous interpretation could be drawn from People v. Simmons, 28 Cal. 2d 699,172 P.2d 18 (1946). Although the court did not require an explicit claim of privilege, the finding that the accused's conduct indicated the adoption of a "policy of silence" may suggest that some intention to refuse to respond, analogous to claiming the privilege, is necessary before the protection of the privilege would be granted.

73 It might be suggested that this merely resurrects a familiar problem involved with all jury trials. In these circumstances, however, the prejudicial effects from allowing a jury to hear the evidence seem difficult to overcome. If the thesis of this comment is accepted-that the inference violates privilege doctrine without regard for its probative value-then to expect a jury to disregard evidence which it perceives as possessing at least some probative value is to expect more than is reasonable. But cf. Stein v. New York, 346 U.S. 156 (1953). 
leading partial disclosure are absent in the police station where no adversary party is present. ${ }^{74}$ Nor is the accused's interest in protecting himself from incriminating disclosure subject to the countervailing interest of a tribunal whose responsibility for determining guilt demands, in the interests of ascertaining truth, a restriction upon the power of a defendant to limit his testimony. ${ }^{75}$ The absence of counsel and the lack of a public and impartial court further suggest that waiver of constitutional rights be found with caution.

Although the scope of waiver should depend upon the pattern of the colloquy, at least the minimum requirements necessary for finding a waiver of the privilege at trial should be maintained. Waiver cannot be found until some incriminating disclosure has been made.76 Thus, complete silence to all police inquiry should present no question of waiver, for no incriminating disclosure has been made. An exculpatory statement, for similar reasons, should not constitute waiver of a later

74 That considerations of fairness are important in determining the scope of waiver at trial is readily seen in opinions which discuss the need for protecting an opposing party from the prejudicial partial disclosure of a witness, for preserving cross-examination as an instrument for testing the veracity of the witness' testimony and for full disclosure to assist the court in its ascertainment of the truth. Brown v. United States, 356 U.S. 148, 154-56 (1958); United Sțates v. St. Pierre, 132 F.2d 837, 840 (2d Cir. 1942), appeal dismissed, 319 U.S. 41 (1945). Commentators have attempted to distinguish adversarial trial proceedings from nonadversarial grand jury proceedings and legislative investigations, but the courts have apparently ignored the distinction. 8 WIGMORE $\S 2276$, at 456-57. Noonan, Inferences from the Invocation of the Privilege Against Self-Incrimination, 41 VA. L. REv. 311 (1955); Note, 70 HARV. L. REv. 1454 (1957); Note, 52 Nw. U.L. REv. 542 (1957); Note, 61 YALE L.J. 105 (1952). It is suggested here that the arrest situation urges the distinction more persuasively.

75 Although interrogation and efficient police investigation may have social value, see Culombe v. Connecticut, 367 U.S. 568 (1961), these interests appear to be of a lower order than that of the court's interest in full disclosure. The court needs to preserve cross-examination as a prophylactic against distortion and perjury so that it may arrive at an equitable determination. In the police station, the possible evils from partial disclosure are not as great; indeed, the interest of the community in interrogation is not based on the necessity of testing veracity but rather on the convenience of obtaining evidence from the accused. This interest of convenience does not seem sufficiently potent to support a waiver doctrine.

76 The original formulation of the scope of waiver was that a witness could not refuse to divulge details after previously admitting his guilt, because the purpose of the privilege-to protect from incriminating disclosure-would not be served. Brown v. Walker, 161 U.S. 591, 597-98 (1896) (dictum); cf. McCarthy v. Arndstein, 262 U.S. 355 (1923); Arndstein v. McCarthy, 254 U.S. 71 (1920). At present, however, waiver can apparently be found in some cases when only some incriminating disclosures have been made. See Rogers v. United States, 340 U.S. 367 (1951). It should be noted that defendants who voluntarily take the stand in their own behalf may be subject to a broader waiver rule than witnesses who are compelled to testify, because the act of testifying signifies a choice to relinquish the privilege of remaining silent. See Brown v. United States, 356 U.S. 148 (1958); Caminetti v. United States, 242 U.S. 470, 493-94 (1917); 8 WIGMORE § 2276. 
right to silence. ${ }^{77}$ The equivocal reply appears to be a borderline case, but analysis must find this response non-incriminatory as well. The equities of the situation might suggest that the accused should be denied the benefits of unprejudiced silence because of a deliberate intent to mislead the interrogator, but this consideration departs from traditional waiver analysis and approaches a theory of estoppel.

The strongest case for finding waiver arises when an admission of guilt is made, but an inquiry as to detail is unanswered or evaded. Since the protection from incriminating disclosure given by the privilege is rendered unnecessary by the admission, waiver could be found with no sacrifice of the accused's privilege to be free from incriminating disclosures. ${ }^{78}$ Facts similar to this situation were present in People $v$. Rutigliano ${ }^{79}$ where the accused confessed but remained silent to an accusation of being the leader. A finding of waiver would seem appropriate, for the accused freely discussed his guilt. ${ }^{80}$

The troublesome problems arise in considering whether some incriminating revelations will be a waiver as to related accusations. ${ }^{81}$ Here, the absence of counsel may be the controlling consideration. If a witness on the stand may be regarded as facing a delicate choice in testifying without forfeiting his privilege in further inquiry, the accused in the police station faces a dilemma more acute. The accused has no tribunal to rule on the question of waiver. Perhaps too severe a standard is imposed by requiring a person in the midst of interrogation to judge for himself without aid of court or counsel whether his previous answers will prevent remaining silent without prejudicial results. Since the considerations of fairness which at trial urge full disclosure are not present in the police station, the interest of the accused in protecting himself from incriminating disclosure arguably should prevail.

77 If the analogy is to the defendant who voluntarily takes the stand rather than the witness who has been compelled to testify (see note 76 supra), waiver could be found. Cf. Brown v. United States, 356 U.S. 148 (1958). Nevertheless, the situation of the accused undergoing police interrogation seems to resemble more closely that of the involuntary witness, since the accused has not demonstrated a willingness to speak which parallels the voluntary assumption by a witness of the testimonial obligation imposed by a court.

78 Problems still remain in finding waiver under these circumstances, however, for perhaps the absence of the protections present at trial will suggest that a wider range of disclosures be protected during arrest than would be protected at trial. Even though incrimination is admitted, is it wise to require the accused, who has spoken in the absence of counsel, to buttress the prosecutor's case?

79261 N.Y. 103, 184 N.E. 689 (1933). See text at notes 88-91 infra.

80 The inference from silence in this type of situation seems to be the inference with the greatest probative value, thus undercutting the argument that it would be unfair to the accused to find a waiver.

81 For the rule at trial see Brown v. United States, 356 U.S. 148 (1958); Rogers v United States, 340 U.S. 367 (1951). 
Whether the inference from the accused's silence should be permitted because the accused's conduct indicates waiver should depend upon the pattern of the colloquy. In applying the doctrine to arrest situations, courts should take notice of the conditions surrounding arrest which make the trial standard for waiver seemingly inappropriate.

IV

The preceding portions of this comment have shown that constitutional analysis of the adoptive admissions problem is appropriate. An attempt has been made to outline that analysis and the connected problems of comment and waiver. It now remains to consider whether other lines of analysis indulged in by the courts are viable.

The majority of jurisdictions which refuse to infer guilt from an accused's silence in the face of accusation made during arrest use reasoning which can be explained only by the doctrine of the privilege against self-incrimination. These jurisdictions base their refusal to entertain the inference upon the proposition that a person has no duty to speak when he is under arrest. ${ }^{82}$ United States $v$. Lo Biondo ${ }^{83}$ is typical. The defendant was apprehended by the police while he was loading unstamped cases of alcohol into an automobile. En route to the station, he was accused of bootlegging, but said nothing. At trial, he was convicted, but the Court of Appeals for the Second Circuit reversed, holding admission of the colloquy to be error since "one under arrest or in custody, charged with crime, is under no duty to make any statement concerning the crime ...." 84

It is clear that the court in Lo Biondo relied upon concepts of the privilege rather than an evidentiary analysis, since it cited McCarthy $v$. United States ${ }^{85}$ another adoptive admissions case, for the proposition that "to draw a derogatory inference from mere silence is to compel the respondent to testify." 86 But even beyond the obvious use of privilege language in the Lo Biondo case, it is submitted that the result could have been justified under no other theory.

The probative value of the defendant's silence as evidence of guilt is not necessarily affected by the fact that an accused is under no duty to speak to police. Under evidentiary analysis, the sole question before the court would be whether a normal innocent person, under the circumstances, would feel called upon to deny the accusations. Although

82 See cases cited note 11 supra.

83135 F.2d 130 (2d Cir. 1943).

$84 \mathrm{Id}$. at 131 .

8525 F.2d 298 (6th Cir. 1928).

86 United States v. Lo Biondo, 135 F.2d 130, 132 (2d Cir. 1943). 
it may be that the accused's awareness that he is under no duty to speak may bear on the probative value of his silence, the court did not pose this question. The Lo Biondo case, at the least, must stand for the proposition that regardless of the probative value of the defendant's silence, absent waiver, it cannot be received as evidence because it occurred during arrest. The only rational explanation for this proposition is that the privilege assures an accused that he may remain silent to police interrogatories. In this light, the problem becomes one of evaluating the propriety of imposing a detriment upon one who has exercised a privilege guaranteed by law-a question which can be answered without regard for the probative value of the inference.

Thus, the cases which assert the proposition that the accused is under no duty to speak when he is under arrest may reasonably be regarded as resting upon the privilege against self-incrimination. Use of "no duty" language makes sense only if understood as referring to concepts derived from the privilege. It may refer to the protection which the privilege affords an accused during arrest by limiting the power of the state to obtain a conviction with the involuntary assistance of the accused, or it may refer to the identity of position of the defendant at trial with the accused at arrest, neither being under an obligation to talk. In either case, the doctrine which controls the result is that determining whether negative inferences can be drawn from use of the privilege.

A few cases can be found which adopt a rule barring the evidence on the grounds that the fact of arrest destroys its probative value. ${ }^{87}$ Even here, the reasoning is buttressed by resort to "no duty" language. In People v. Rutigliano, 88 the defendant was charged with kidnapping and confessed to a substantial part of the crime. Nevertheless, when a codefendant made statements while both were in custody which implicated the defendant as the ring leader of the plot, the defendant stood mute. In excluding this evidence the New York court used language which could be regarded as following either an evidentiary analysis or a no duty formulation. The significant paragraph of the opinion follows.

87 Commonwealth v. Sazama, 339 Mass. 154, 158 N.E.2d 313 (1959) (dictum); People v. Rutigliano, 261 N.Y. 103, 184 N.E. 689 (1933). Wharton remarks that courts have found the fact of arrest a sufficient restraint to destroy the inference of guilt from an accused's silence. 2 Wharton, Criminal Evidence § 661, at 1102 (1l th ed. 1935); cf. 4 Wigmore $\S 1072$, at 80-81. Although cases can be found which exclude the inference from silence during arrest because of a lack of probative value under the particular circumstances, e.g., State v. Brown, 209 Minn. 478, 296 N.W. 582 (1941) (dictum), this writer has discovered very few cases which stand for the proposition that arrest always destroys the probative value of an inference of guilt from an accused's silence. Much more typical is the "no duty" language which is seen in the cases cited at note 11 supra; O'Hearn v. State, 79 Neb. 513, 113 N.W. 130 (1907).

88 People v. Rutigliano, 261 N.Y. 103, 184 N.E. 689 (1933) (dictum). 
No cautious person, when in custody, accused of crime would care to enter into a discussion of his guilt or innocence with his captors and co-defendants, when what he said might be used against him. It cannot be said that "the declaration was [in such circumstances] in substance a challenge to [him] to assert [his] innocence if [he] were not guilty." ... He is then under no duty. to speak and his silence should not be counted as giving assent to what he hears. If he had counsel, he would doubtless be advised not to talk. If he had not, he should not be prejudiced thereby. ${ }^{89}$

The excerpt from Rutigliano well illustrates the confusion between two distinct arguments: (a) that it is not reasonable to expect a normal innocent person to deny accusations made by alleged accomplices while he is under arrest and (b) that the accused, during arrest, is under no duty to speak.

The second argument has been discussed above and found to rest on the privilege against self-incrimination. The first cannot support the court's adoption of a per se rule, for evidentiary analysis does not exclude, in every case, inferences from an accused's silence during arrest. ${ }^{90}$

On the facts of Rutigliano, it is difficult to understand how the defendant could have been reluctant to "enter into a discussion of his guilt or innocence" when he had in fact confessed to substantial participation. Since his previous conduct indicated a willingness to speak, the possibility that he feared discussing his involvement with the police is negated. His silence in the face of the most damaging accusation directed to him thus makes reasonable the inference that failure to deny indicated a consciousness of guilt. Considering the situation solely in terms of the probative value of the inference, it seems reasonable to conclude that Rutigliano, despite its reasoning to the contrary, presents an easy case for use of adoptive admissions theory.

Perhaps Rutigliano can be justified on the grounds of ease of administration. 91 Although it is recognized that even under arrest a defendant's silence may in some instances support an inference of guilt, selecting the appropriate cases is so difficult that a per se rule is adopted for reasons of certainty.

If Rutigliano illustrates that the per se rule cannot be justified on grounds of lack of probative value, but must depend upon administrative considerations of certainty and simplicity, several problems arise. First,

$89 \mathrm{Id}$. at 107,184 N.E. at 690.

90 Wigmore takes the position that arrest should be considered as but one factor in determining whether an inference of guilt is appropriate. 4 WIGMORE $\$ 1072$, at 81 . Accord, People v. Simmons, 28 Cal. 2d 699, 172 P.2d 18 (1946) (dictum).

91 People v. Rutigliano, 261 N.Y. 103, 107, 184 N.E. 689, 690 (1933). 
the certainty of the rule may be illusory. In Rocchia $v$. United States, the court explicitly acknowledged its departure from the general rule excluding inferences from silence during arrest and stated that the defendant should have replied to an accusation of bribery. Rocchia, although an extreme case, undercuts the contention in Rutigliano that an adoptive admissions theory for arrest is uniformly difficult to administer, for the court had no trouble in finding on the particular facts that the inference was appropriate. Indeed, Rocchia suggests that the stability of the per se rule is beguiling-once the reason for the rule, ease of administration, ceases, corrosion of the rule begins. Second, certainty and simplicity may be purchased at the price of irrationality, for some states have distinguished the situations where the accused was under arrest from the situations where he was only in police custody. It is straining analysis to say that an inference of guilt is appropriate during police custody but destroyed by arrest. ${ }^{93}$

It is submitted that Rutigliano and cases like it, by adopting a strict rule during arrest, are actually injecting considerations extraneous to evidentiary reasoning into their analysis. In Rutigliano, the court's statement that the accused should not be prejudiced by his failure to speak when he was under no duty to do $\mathrm{so}^{94}$ articulates its conviction that basic notions of fairness would be offended by following any other rule. These considerations involve an appraisal of the limits upon state power in obtaining a conviction and an evaluation of the exercise of that power against fundamental notions of fairness. But the standard for evidentiary analysis is probative value, and the rules of evidence are insensitive to considerations of fairness. Unless the case is read as resting upon policy, and, most probably, the privilege against self-incrimination which the "no duty" language suggests, fairness is irrelevant. Since evidentiary analysis cannot support Rutigliano, the conclusion must be that this case also stands for the proposition that the privilege against selfincrimination prohibits inferring guilt from an accused's silence during arrest.

9278 F.2d 966 (9th Cir. 1985) (dictum) (ordinarily a defendant is entitled to remain silent when under arrest, but this situation called for a reply. $I d$. at 972). See McCarthy v. United States, 25 F.2d 298 (6th Cir. 1928) (per curiam) (dictum).

93 In Massachusetts, no inference of guilt is permitted after the accused has been arrested. Commonwealth v. McDermott, 123 Mass. 440 (1877); Commonwealth v. Kenney, 12 Met. 235 (Mass. 1847). But in Commonwealth v. Sazama, 339 Mass. 154, 158 N.E.2d 313 (1959), the court refused to invoke the rule (dictum). A police officer, questioning the defendant, told him he was not under arrest, but then said "I am accusing you of a crime ... what do you have to say?" Id. at 156, 158 N.E.2d at 315. Cf. Owens v. Commonwealth, 186 Va. 689, 43 S.E.2d 895 (1947).

04 See quote in text at note 89 supra. 
At the outset, four categories of cases were considered: (1) those using the privilege to prohibit inferring guilt from silence during arrest; (2) those using "no duty" language to bar the inference; (3) those adopting a per se evidence rule to reach the same result, and (4) those permitting an inference of guilt to be drawn even though the accused is under arrest. It has been shown that both history and analysis indicate that the first group of cases correctly apply privilege doctrine. Further, the "no duty" cases can only be understood as applying the privilege. Finally, the cases which purport to adopt a per se rule of evidence cannot be justified except on grounds of extrinsic policy unrelated to probative value. Thus all the cases which categorically exclude inferences of guilt from silence during arrest depend upon doctrine of the privilege or bear marked resemblance to that doctrine, the inferences being prohibited because of constitutional and statutory provisions forbidding comment on the exercise of the privilege at trial.

Those cases in the last category represent pure evidentiary analysis, since silence during arrest may or may not be admissible depending upon its probative value. It is submitted that the arguably constitutional status of the rules barring comment casts serious doubt upon these cases. The policy of the privilege so informs this problem that purely evidentiary analysis is singularly inappropriate.

At the least it is clear that the courts have not engaged in probing analysis of this problem. Even those courts which have applied the privilege to bar the admission of silence during arrest have failed to recognize the controlling significance of the rules as to comment ${ }^{95} \mathrm{It}$ is to be hoped that current reasoning will give way to an approach which recognizes the unity of the position of the accused at arrest and the defendant at trial.

95 Paradoxical results have been reached in California where the privilege has been explicitly recognized during arrest. People v. Clemmons, $153 \mathrm{Cal}$. App. 2d 64, 76, 314 P.2d 142, 150 (1957). The California constitution permits comment upon a defendant's exercise of the privilege at trial, but the relevance of the rule to arrest has been ignored. The inference from silence during arrest will at times be prohibited as a violation of the accused's privilege against self-incrimination, despite the fact that a contrary rule of inference exists at trial. See People v. Simmons, 28 Cal. 2d 699, 172 P.2d 18 (1946). 